ISSN: 1984-6266

\section{From the financial crisis to the Balance Sheet recession: an empirical analysis based on the National Accounts}

\author{
Virgínia Granate Costa e Sousa \\ Instituto Superior de Contabilidade e Administração da Universidade de \\ Aveiro - ISCA -UA / Portugal \\ virginiagranate@ua.pt
}

\begin{abstract}
The crisis entitled as systemic, financial, sovereign debt or the balance sheet recession, seems to be prepared to survive, assuming several forms and dynamics. In fact, the actual systemic crisis makes clear the interconnections of all institutional sectors (mainly between the financial and the general governments sector) and highlights the relevance of the system of macro accounting (European System of Accounts - ESA) to be used for several purposes: as a system of information for analysing the economic and the financial context, to prevent the fiscal distress and as a framework to make possible the national and the supranational governance and regulation. The systemic nature of the financial crisis and its dynamics are the fundamentals of this paper and the observation framework, applied to five countries of the Euro Area, is sustained by the (ESA2010) and by the supplementary tables for reporting government interventions to support financial institutions. The ratios construction and analysis is supported by the supranational governance framework point of view for macroeconomic imbalances procedure (MIP). In fact, the MIP framework, designed with several and diversified indicators is, in crisis time, fundamental for the construction of the financial stability, the growth and the employment. In this paper it is underlined the fragility of some Euro Area Member States, mostly when in the absence of the European Central Bank as a lender of last resort. I conclude with two remarks: the so called "deadly embrace" between the general government and the financial sector is, nowadays, in a financial systemic crisis context, accompanied by a balance sheet recession, concerning all the institutional sectors of a country and its interactions with the Rest of the World; and the national and international governance strategies must be guided by the concern that all the sectors are too big to fall.
\end{abstract}

Keywords: Macroeconomic Imbalances; Systemic risk; liquidity crisis; financial stability; governance.
Recebimento:

27/03/2017

Aprovação:

12/12/2017

Editor responsável pela aprovação do artigo:

Dr. Flaviano Costa

Editor responsável pela edição do artigo:

Dr. Flaviano Costa

Avaliado pelo sistema:

Double Blind Review

A reprodução dos artigos, total ou parcial, pode ser feita desde que citada a fonte.

PROGRAMA DE PÓS-GRADUAÇÃO EM CONTABILIDADE MESTRADO E DOUTORADO

DOI:

http://dx.doi.org/10.5380/rcc.v9i3.51434 


\section{Introduction}

Financial crises are not so unusual but they assume, as the time goes on, different shapes related to the institutions evolution and their interlinkages. Since the beginning of the actual crisis - the greater after the 1929-1933 - we can observe an accelerating change of financial institutions from holding loans on its balance sheet to relying on securitisation as a way of increasing its profits and evading from the need to raise liabilities to cover its assets.

A banking crisis tends to evolve into a financial sector global crisis, but he financing linkages and the wealth dynamics may activate a crisis felt by all the institutional sectors of a Country and of the whole Euro Area. The big challenge is to prevent a vicious circle, where a crisis of the public sector may, again, led to crisis development in the financial system - the systemic risk that spreads to all the economic system and trigger the economic recession (Nowotny, 2010, p. 5).

We are crossing the time of assuming that the role of the banks, as the main holders of government debt, and of the financial market are sources to understand the unbalanced nature of the economic and financial system: also, we must remind that, at the same time, governments have a strategic action by its intervention on the financial sector. It is the scenario of the fatal interlinkages that calls for a strategic action of the European Central Bank (ECB).

Meanwhile, Central Banks are learning how to deal with the instability and have been increasing and assuming the role of lenders of last resort - injecting liquidity, when necessary, in the financial market and purchasing government bonds for preventing the "deadly embrace" between the sovereign and the banks (Grauwe, 2013, p. 3).

The banks classified by the European System of Accounts (ESA2010) inside the financial corporation sector (S12), and as the main holders of government debt, have a similar balance sheet structure when compared with the general government sector (S13) and "in absence of a lender of last resort, a collective movement of distrust can lead to a liquidity crisis that can push the government into default" (Grauwe, 2013, p. 4).

In this complex crisis context, the recommended lender of last resort (LOLR) must be the European Central Bank. In fact, for responding to the worst financial crisis in the century the ECB "faced two challenges" with different approaches: the monetary approach; and the credit approach or the interventions in solvent credit institutions in the context of LOLR "which is embedded in the Eurosystem's emergency liquidity assistance (ELA) - a responsibility of the national banks" (Praet, 2016, p. Introduction).

The ECB is a money creating institution with the capacity of buying government bonds and is the salvation for the limited resources of the European Stability Mechanism (ESM) created to provide financial assistance to countries with financing problems, safeguarding the financial stability of the Euro Area as a whole and of its Member States (Sousa, 2011, pp. 212-224).

But we may ask: the new roles and performance of the ECB are sufficient to the survival of the monetary union? In this context, some claims for a Banking Union and others for a Fiscal Union. I argue that good governance, at the national and the European levels, is the strategy for the crisis and the recession. In fact, at the supranational level we have a "watch dog" struggling for the welfare of the European countries: It is the Macroeconomic Imbalance Procedure (MIP); this instrument could be a good answer if applied by European Member States for the improvement of the economic and financial governance, in a crisis context.

The (MIP) is a surveillance mechanism to detect and report economic trends that may badly distress the performance of a Member State, the euro area, or the EU: it has several purposes: to identify potential risks in advance; to prevent the emergence of dangerous macroeconomic imbalances; and to correct the imbalances in place.

The annual starting point of the MIP is the Alert Mechanism Report (AMR); it is supported by a scoreboard of indicators, complemented by a publication Report from the Commission, prepared in accordance with Articles 3 and 4 of Regulation (EU) $n^{0}$ 1176/2011 on the prevention and correction of macroeconomic imbalances (European Commission, 2016). 
The AMR identifies countries for which a closer analysis (in-depth review) is considered necessary. The outcome of these in-depth reviews forms the foundation for additional steps under the MIP, in the intention of a graduated approach and monitoring to stop the severity of the imbalances. The Commission may propose Council's recommendations to countries identified with imbalances: countries in the stage of excessive imbalances would be subject to a specific monitoring or could enter in the Excessive Imbalance Procedure, followed by eventual sanctions.

The MIP framework, designed with indicators, is fundamental for the construction of the financial stability, the growth and the employment, in time of crisis. The main information supports to construct the referred indicators are: The European System of Accounts (ESA 2010) (Eurostat \& European Commission, 2013); The Balance of Payments and International Investment Position Manual, sixth Edition (BPM6) (International Monetary Fund, 2009); The Consistency Between National Accounts and Balance of Payments (Eurostat, 2016 a) ; and the Supplementary Tables for Reporting Government Interventions to Support Financial Crisis (Eurostat, 2016 b). And, once more (Sousa, 2012) the systems of information are the fundamentals for the governance strategies.

\section{Empirical Study}

\subsection{Study Characterisation}

This empirical study is based on the European System of Accounts (ESA 2010) as it is "an internationally compatible accounting framework for a systematic and detailed description of a total economy, its components and its relations with other total economies " (Eurostat \& European Commission, 2013, p. 1).

The sector accounts by institutional sector allow a systematic description of the different stages of the economic process and the construction of some important indicators for the general government sector (S13); the sector accounts include, also, the Balance Sheets for describing the stocks of assets, liabilities and the net worth, at the end of the accounting period.

The study is, as well, supported by the Supplementary Tables for Reporting Government Interventions to Support Financial Institutions - as a crucial framework for the analysis of the interactions between general government sector and the financial sector. The study period is between 2009 and 2014 (2015) for the reasons of the information data updates: for Annual Accounts by Institutional, in ESA Format, the 28 April 2016; for the Supplementary Tables its last update of 31 March or April, 2016.

Five countries in the study open the analysis of some particularities, by country, in the Macroeconomic Imbalances Procedure, and invite to discover the diversified links between the general government and the financial sector. The same countries allow the analysis of the net financial worth or wealth (in percentage of GDP) by means of their Balance Sheets by institutional sectors: the non-financial corporations (S11); the financial corporations (S12); the general government (S13); the households (S14) and the non-profit institutions serving households (S15); and all the country (S1).

The presentation by sectors reveals many key measures and indicators for economic and financial policy purposes, at the national and supranational levels. 


\subsection{Macroeconomic Imbalances Procedure: Links between the general government and the financial sectors}

Austria subject to in-depth reviews, for the first time, in 2016, was - according to Macroeconomic Imbalances Reports (MIP), changes in MIP categories and Member States categorization, 2015-2016 categorized in no imbalances in the same year (European Union, 2016).

From 2009 Austria were in an excessive deficit situation what's make the European Commission to address a Recommendation for bringing the Austria to assume the compromise to end by 2013.

The abrogating decision, justified by the deficit from 2011 to 2014 (bellow 3\%) was published (Council of the European Union, 2014 a) to end the process. Besides, the deficit is decreasing, between 2009 and 2013 (Figure 1), what's make the process of adjustment much more credible.

Figure 1: Austria - General Government Deficit (B9), in percentage of GDP

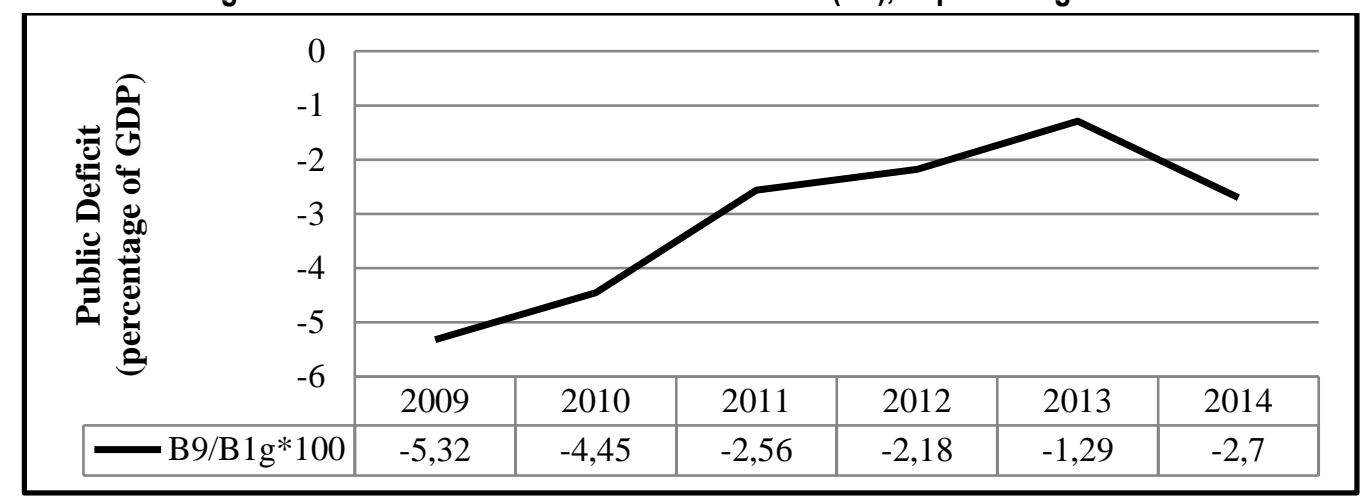

Source: own elaboration: based on Annual Accounts by Institutional Sector, Austria, last update 28 April, 2016, in millions of national currency, euro fixed series, current prices (Eurostat, $2016 \mathrm{c}$ )

The year of 2014 makes the alert! The costs related to the establishment of HETA (the win-down vehicle for the impaired Assets of the former Bank - Hypo Alpe Adria - make the deficit go up in 2014 (European Commission, 2015 a, p. 105).

The wind-down unit is in burden of managing its assets as a method of ensuring the organized and active disposition of its assets on the best terms possible.

HETA ASSET RESOLUTION AG is a wind-down company owned by the Republic of Austria. Its statutory task is to dispose (as effectively as possible whilst preserving value) of the non-performing Assets of Hypo Alpe Adria, nationalised in 2009. HETA ASSETS RESOLUTION AG, in the interest of the taxpayer, assumes responsibility for the assets that it has taken over from the former Hypo Alpe-Adria-Bank International $A G$ and this action is committed for the best-possible risks reduction.

The framework for the resolution of Hypo Alpe-Adria-Bank International AG was adopted by the Austrian Council of Ministers on June 2014. This framework provided for classify the bank's assets into core and noncore, is associated to the purpose of transferring the latter onto a "bad bank" or a vehicle for a special purpose. Finally the core banking assets were transferred for the Hypo SEE-Holding, renamed as Hypo Group Alpe Adria AG.

In this development, HETA informed its owner, the Republic of Austria, that it was running the risk of insolvency. The process goes on the resolution, not the insolvency - for the public interest. The Financial support was made by the Financial Market Authority (FMA) - under the Federal Act on the Recovery and Resolution of Banks (Osterreichische National Bank -ONB, 2015, p. 22).

Austrian Banks should continue to strive for capital levels because of their risk exposures. The Belgium National Bank (ONB) and the Financial Market Stability Board (FMSB) recommends the activation of the 
From the financial crisis to the Balanced Sheet recession: an empirical analysis based on the National Accounts.

systemic risk buffer (SRB). Besides, banks and insurances must review their "business models" to increase their profitability and survival in a low interest rate environment (Osterreichische National Bank -ONB, 2015, p. 9)

And again, the interlinkages general government - financial sectors appear as evident to increase the debt ratio by the process "of inclusion, under general government debt, of the HETA ASSETS RESOLUTION AG liabilities, established in 2014" (European Commission, 2015 b, p. 8).

I must highlight that the Austrian gross debt (\% of GDP) rises, again, in 2015 (Table 1) forced by the inclusion "into the General Government debt, of the financial assets transferred from Kommunal - Kredit Austria A.G. to the balance sheet of KA Finanz" (European Commission, 2015 b, p. 9), in accordance with the General Government accounts for the application of ESA 2010 methodology (Eurostat \& European Commission, 2013).

Table 1: General Government (S13) Gross Debt (in accordance with Maastricht criteria)

\begin{tabular}{|l|r|r|r|r|r|r|r|}
\hline & $\mathbf{2 0 0 9}$ & $\mathbf{2 0 1 0}$ & $\mathbf{2 0 1 1}$ & $\mathbf{2 0 1 2}$ & $\mathbf{2 0 1 3}$ & $\mathbf{2 0 1 4}$ & $\mathbf{2 0 1 5}$ \\
\hline Austria & 79,7 & 82,4 & 82,2 & 81,6 & 80,8 & 84,3 & 86,2 \\
\hline Belgium & 99,6 & 99,7 & 102,3 & 104,1 & 105,2 & 106,5 & 106 \\
\hline Netherlands & 56,5 & 59 & 61,7 & 66,4 & 67,9 & 68,2 & 65,1 \\
\hline Portugal & 83,6 & 96,2 & 111,4 & 126,2 & 129 & 130,2 & 129 \\
\hline Spain & 52,7 & 60,1 & 69,5 & 85,4 & 93,7 & 99,3 & 99,2 \\
\hline Euro Area - 19 & 78,3 & 83,8 & 86 & 89,3 & 91,1 & 92 & 90,7 \\
\hline
\end{tabular}

Source of Data: Eurostat (Last update: 25-04-2016).

Note: National Accounts does not show the consolidated gross debt.

But the interlinkages GG and the Financial Corporations Sector appears under several forms, even when there are outstanding amount of assets, actual liabilities and contingent liabilities of general government; in this case they are reported by the Supplementary Tables for Reporting Government interventions to Support Financial Institutions (Table 2).

Table 2: Austria - Outstanding amount of Assets, actual Liabilities and Contingent Liabilities of General Government (S13)

\begin{tabular}{|l|r|r|r|r|r|r|r|}
\hline & 2009 & 2010 & 2011 & 2012 & 2013 & 2014 & 2015 \\
\hline Assets-Liabilities & 17593 & -962 & -2414 & -3539 & -5164 & -2188 & -4724 \\
\hline BF90 (S13) & -142921 & -151520 & -163397 & -178064 & -177317 & -195308 & na \\
\hline Assets-Liabilities (\% of BF90 from S13) & $-12,3$ & 0,6 & 1,5 & 2,0 & 2,9 & 1,1 & na \\
\hline Contingent Liabilities & 16551 & 15630 & 10048 & 6384 & 3156 & 100 & 1700 \\
\hline Contingent Liabilities (\% of BF90 from S13) & $-11,6$ & $-10,3$ & $-6,1$ & $-3,6$ & $-1,8$ & $-0,1$ & na \\
\hline
\end{tabular}

Sources: own elaboration: based on Supplementary table for reporting government interventions to support financial institutions, Austria, 31-03-2016 (Eurostat, 2016 d) and on Annual Accounts by Institutional Sector, Austria, last update 28 April, 2016 , in millions of national currency, euro fixed series, current prices (Eurostat, $2016 \mathrm{c}$ ).

This table clarifies the consequences of the interlinkages - general government sector (S13) and the financial corporations sector (S12). In the period of 2009-2015 all the general government interventions (with the exception of the one in 2009) make the general government financial wealth (Assets-Liabilities) worse. Between, 2011-2014, with some variations, we can see the worst results (even when expressed in percentage of the general government net financial worth (BF90).The contingent Liabilities (expressed in percentage of general government BF90) between, 2009-2014, are heavy (mainly in the four first years) but decreasing what is a good notice when concerning the public debt. 
Belgium, in 2015, was in macroeconomic imbalances and, for that reason, subjected to policy actions and monitoring. After a year of well succeeded measures, Belgium, according to Macroeconomic Imbalances Reports (MIP), changes in MIP categories and Member States categorization, 2015-2016, was categorized in no imbalances in 2016 (European Union, 2016).

Also, the abrogation of the EDP in June 2014 implied for Belgium to be subject to a "period of three years to comply with the debt reduction benchmark, starting in 2014" (European Commission, 2016 a, p. 6).

Some strategic policy actions were applied but, public debt remains high and will "stabilize around 107\% of GDP, in 2016" (European Commission, 2015 c, p. 1).

In fact the accumulation of deficits, following the economic and financial crisis, as well as the intense interventions in the financial corporations sector and the "subdued GDP growth" (European Commission, 2016 a, p. 5) were the main reasons for the Belgium to face a sovereign debt crisis.

But, many relevant issues may be described as justifying the categorization of Belgium as an imbalance (not in the stage of excessive) country in 2016:

[1] The amount and the systemic relations between the government investment (in percentage of GDP) and the public deficit (in percentage of GDP).

[2] Structural reforms with visible impact on growth.

[3] High public indebtedness complemented by a debt maturity strategy.

[4] The healthy financial state of the private sector, mainly the households sector, as a crucial reply for the high public debt.

[5] The problem of refugees and the severity of the terrorist threat are considered "as unusual and exceptional events outside the general government control"

(European Commission, 2016 a, p. 11).

Since the start of the financial crisis the Belgium government debt is very large (declined in 2015) but the deficit is it on the limits? (Figure 2)

The tendency of the public deficit is good (around 3\% of GDP) in 2013 and 2014, but the massive interventions in the financial sector may compromise the future.

Figure 2: Belgium - General Government Deficit (B9), in percentage of GDP

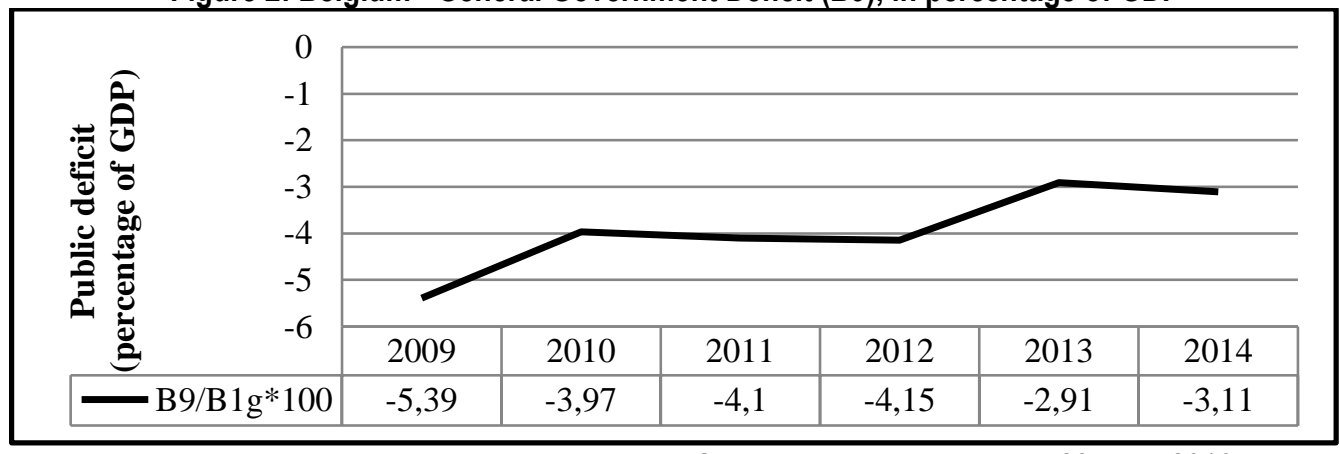

Source: own elaboration: based on Annual Accounts by Institutional Sector, Belgium, last update 28 April, 2016, in millions of national currency, euro fixed series, current prices (Eurostat, 2016 c) .

Nevertheless, despite the high public indebtedness (Table 1), always present in the Belgium economy of the recent decades and one of the biggest in the EA (19), the net financial position of the country, as a whole, is highly positive mainly because of the households sector, with a comfortable net financial wealth which more than offset the net liabilities of the public and of the non-financial corporations (European Commission, $2016 \mathrm{a}$, pp. 14-15). This scenario opens the guarantee to defend the Belgium from a future risk of financial stress.

We must consider, also, that the reclassification of corporations into the general government sector, in accordance with the European System of Accounts (ESA) 2010 (Eurostat \& European Commission, 2013), result in an increase of the gross debt; "the reclassification units consisted of investment vehicles of regional authorities but this was accompanied by an increase in government fixed assets" (European Commission, 2015 c, p. 26). 
From the financial crisis to the Balanced Sheet recession: an empirical analysis based on the National Accounts.

In spite of all, the high public debt and its stabilization, for "around 107\% of GDP in 2016" (European Commission, 2015 c, p. 1), highlight the relevance and the danger of the contingent liabilities of the general government, related to the financial corporations' guarantees. The following Table 3 opens some actions interpretation and indicates some government procedures for the sectors in place.

Table 3: Belgium - Outstanding amount of Assets, actual Liabilities and Contingent Liabilities of General Government (S13)

\begin{tabular}{|l|r|r|r|r|r|r|r|}
\hline & 2009 & 2010 & 2011 & 2012 & 2013 & 2014 & 2015 \\
\hline Assets-Liabilities & -1902 & -3124 & -7237 & -4341 & -1252 & -1868 & -465 \\
\hline BF90 (S13) & -289728 & -298334 & -315734 & -356406 & -335550 & -401692 & na \\
\hline Assets-Liabilities (\% of BF90 from S13) & 0,7 & 1,0 & 2,3 & 1,2 & 0,4 & 0,5 & na \\
\hline Contingent Liabilities & 62047 & 55829 & 46960 & 59057 & 45356 & 37565 & 31506 \\
\hline Contingent Liabilities (\% of BF90) & $-21,4$ & $-18,7$ & $-14,9$ & $-16,6$ & $-13,5$ & $-9,4$ & na \\
\hline
\end{tabular}

Sources: own elaboration: based on Supplementary table for reporting government interventions to support financial institutions, Belgium, 11-04-2016 (Eurostat, 2016 d) and on Annual Accounts by Institutional Sector, Belgium, last update 28 April, 2016, in millions of national currency, euro fixed series, current prices (Eurostat, $2016 \mathrm{c}$ ).

In fact, the table clarifies the consequences of the interlinkages - general government sector (S13) and the financial sector (S12). In the period 2009-2015 all the general government interventions make the general government wealth (Assets-Liabilities) worse.

Between, 2009-2012, with some variations, we can see the worst results (even when expressed in percentage of the general government Net Wealth (BF90).

The contingent Liabilities (expressed in percentage of the BF90 of the general), between, 2009-2014, are heavy (mainly in the five first years) but decreasing (with the exception of 2012) and reaching a better result in 2014;they have a decreasing tendency, in nominal value and in percentage of the Net Financial Wealth of the General Government (BF90), but, even so, the failing of several financial institutions, under the financial crisis "pushed public finances into the red" (European Commission, 2015 c, p. 4). Some distress is related with the guarantee scheme for Dexia, which is partly owned by the State of Belgium. Other financial corporations are inside the GG (so they are not in the table). They are: the Belfins - one of the four big banks on the market owned by the Federal State; and the insurance company Ethias - owned by federal and regional authorities: It is important to consider that their capital needs might have an adverse impact on government gross debt (European Commission, 2015 c, p. 28).

Netherlands, on 2 December 2009, following a recommendation from the Commission, the Council decided, in accordance with the decision 2010/287/EU, that an excessive deficit existed in the Netherlands. The Council noted that de deficit planned for the general government (GG) in 2009 was above the $3 \%$ of GDP; at the same time the planned gross debt of GG, in 2009 , was below the reference value of $60 \%$; latter on, both were revised up to $5,6 \%$ and $60,8 \%$ respectively. In final, the Council addressed a Recommendation to the country of Netherlands to take measures for the correction, until 2013. After this recommendation, another followed the first on the basis of unexpected adverse economic events, with critical consequences for the GG finances: Netherlands has to correct the excessive deficit situation until 2014 (Council of the European Union, 2014 b, p. 2).

From 2014, the year that follows the excessive deficit correction, this Country is subject to the preventive arm of the Stability and Growth Pact but, in accordance with the Article 126 (12) of the Treaty, and because of the correction of the excessive deficit, the Decision 2010/287/EU "should therefore be abrogated" (Council of the European Union, 2014 b, p. 6).

But, in the consideration of the last revision of ESA, what is the GG deficit for the period of 2009-2014? (Figure 3). In fact, the deficit of Netherlands is below 3\% of GDP, in 2013 and 2014, and its decreasing tendency is very clear since the year of 2009. The governance strategy for growth, at least from 2014, conducted by the domestic demand, has been favorable to the reduction of the deficit in percentage of the GDP. 
In fact, "The economy of the Netherlands grew strongly in the fourth quarter of 2014" (European Commission, 2015 a, p. 102) motivated by domestic consumption and for the investment growth. Also, in "2016 and 2017, the Netherlands economy is expect to grow 1,7\% and 2\% respectively" (European Commission, 2016 b, p. 102), driven by a strong growth of domestic demand. As a result of a persistent economic recovery, "the deficit declined in 2015 to 1,8\% of GDP" (European Commission, 2016 b, p. 103).

Figure 2.2.3: Netherlands - General Government Deficit (B9), in percentage of GDP

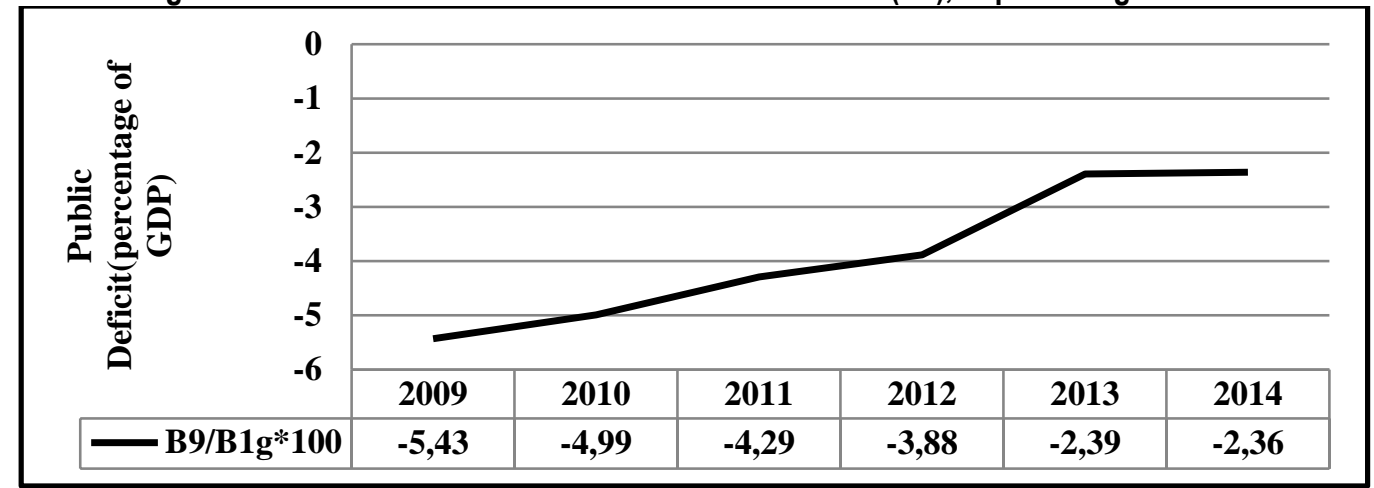

Source: own elaboration: based on Annual Accounts by Institutional Sector, Netherlands, last update 28 April, 2016, in millions of national currency, euro fixed series, current prices (Eurostat, $2016 \mathrm{c}$ ).

And the GG consolidate gross debt, for the same period?

The Netherlands GG gross debt is the best, even in comparison with the Euro Area - all over the period of 2009-2015 - with a little exception (Spain) in the first year of the analysis period (Table 1).

The Netherlands, in the year of 2015, is subject to the preventive arm of the Stability and Growth Pact. The Country was classified in Imbalance, which require decisive policy action and monitoring (European Union, 2016).

"The Government debt was on a decreasing trend before the crisis" (European Commission, Directorate General, Economic and Financial Affairs, 2015 a, p. 9) but increased between 2009 and 2014. The annual accumulation of general government deficits between 2009 and 2012, and the support of the financial sector are relevant factors for the debt dynamics. A "possible re-privatization of parts of ABN - Amro" (European Commission, 2015 a, p. 103) it is important to consider by the reason of it positive effects on the debt government ratio that represents $65,1 \%$ of the GDP, in 2015.

Finally, we must discuss the Netherlands links between the general government and the financial corporation sectors, by the information support of the supplementary table for reporting government interventions to support financial institutions and the ESA (Table 4).

Table 4: Netherlands - Outstanding amount of Assets, actual Liabilities and Contingent Liabilities of General Government (S13)

\begin{tabular}{|l|r|r|r|r|r|r|r|}
\hline & 2009 & 2010 & 2011 & 2012 & 2013 & 2014 & 2015 \\
\hline Assets - Liabilities & -1791 & -2816 & -1159 & -1027 & 1002 & 1711 & -1559 \\
\hline BF90 (S13) & -169057 & -201651 & -236070 & -253129 & -257552 & -287070 & $\mathrm{na}$ \\
\hline Assets - Liabilities (\% BF90 from S13) & 1,1 & 1,4 & 0,5 & 0,4 & $-0,4$ & $-0,6$ & $\mathrm{na}$ \\
\hline Contingent liabilities & 79462 & 39948 & 34125 & 18192 & 10843 & 0 & 0 \\
\hline Contingent Liabilities (\% of BF90 from S13) & $-47,0$ & $-19,8$ & $-14,5$ & $-7,2$ & $-4,2$ & 0 & 0 \\
\hline
\end{tabular}

Sources: own elaboration: based on Supplementary table for reporting government interventions to support financial institutions, Netherlands, 31-03-2016 (Eurostat, 2016 d) and on Annual Accounts by Institutional Sector, Netherlands, last update 28 April, 2016, in millions of national currency, euro fixed series, current prices (Eurostat, 2016 c) . 
As observed in the period of 2009-2015 only the general government interventions in the financial sector between, 2013-2014, have a positive effect on the general government (S13) financial wealth (Financial Assets - Financial Liabilities). But, we may pay attention to the general government negative financial wealth (BF90), all over the period 2009-2014.

In the period 2009-2012 and, again, in 2015, the interventions on the financial sector by general government worsen its financial wealth (BF90). In the two first years of the analysis period, the Assets-Liabilities ratio, expressed in percentage of the general government financial wealth, is very expressive, assuming in 2009 and in $2010,1,1 \%$ and $1,4 \%$ respectively.

The Contingent Liabilities, in percentage of the BF90 of the general government in the period 20092015, have a decreased tendency (with zero in 2014 and 2015) forced by the convergence governance strategies of the Netherlands financial sector and the European Union.

In fact, in the comments (as Countries may explain their national data in the special comments column) of the supra referred Supplementary Table, we can read the following information: "ABN AMRO/ASR has been recorded at net acquisition value for 2008-2014. The valuation of ABN AMRO for 2015 is at market value based on the price of quoted shares whereas the market valuation of ASR has been estimated.

SNS REAAL has been recorded at acquisition value for 2013 and 2014. The valuation of SNS Bank is at market value for 2015, based on the observed selling price in 2015" (Eurostat, 2016 b).

In 2008 SNS REAAL "by the agreement of the Ministry of Finance and the Nederlandsche Bank (DNB), received a capital reinforcement to remain a healthy and well-managed insurance company that has a strong capital buffer" (De Nederlandsche Bank, 2008). Latter, in February of 2013, SNS was nationalized, under the new intervention Act, in force since June 2012 (De Nederlandsche Bank , 2014 a).

After all these measures, at the beginning of 2014 the Dutch financial sector was still in a complex process of recovering from the financial crisis that remains active in the Euro Area. The crisis systemic nature demands a careful and constant surveillance and strategic governance actions.

Netherlands remains, in 2016, in imbalance, in spite of the projections of growth for 2016 and 2017.

In fact, an effective and very persistent crisis management strategy is considered necessary for the safeguard of the state's aid consequences on the public finances and for a healthy financial system (De Nederlandsche Bank, 2014 b).

Portugal is subject, in 2015, to the corrective arm of the Stability and Growth Pact. It must be clarified that the "Council opened the Excessive Deficit Procedure for Portugal on 2 December 2009" and the country is "recommended to correct the excessive deficit by 2015" (European Commission, Directorate General, Economic and Financial Affairs, 2015 b, p. 3).

In fact, Portugal had high public deficits, between 2009 and 2014 (Figure 4) and even in 2015, with 4,4\% the general government deficit does not accomplish the $3 \%$ of GDP, with measures of solid tax collection and expenditure control. There is, however, a risk on the deficit "concerning the statistical recording of the financial sector support measure" related to Espírito Santo Bank (European Commission, 2015 a, p. 109). I may highlight that the referred deficit "contains the fiscal impact of the Banif bank resolution one-off operation worth about 1,4\% of GDP" (European Commission, 2016 b, p. 109). 
Figure 4: Portugal - General Government Deficit (B9), in percentage of GDP

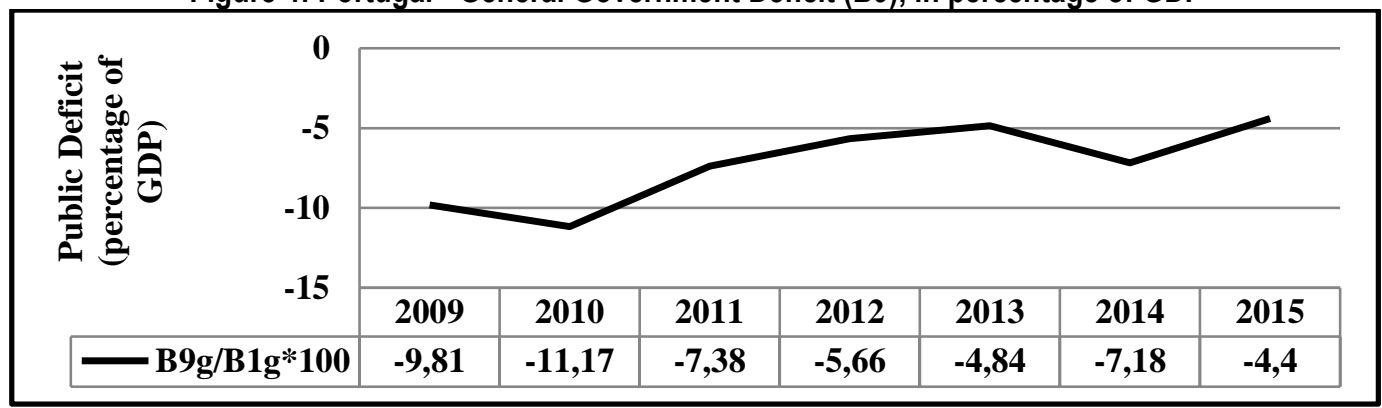

Source: own elaboration: based on Annual Accounts by Institutional Sector, Portugal, last update 28 April, 2016, in millions of national currency, euro fixed series, current prices (Eurostat, 2016 c).

In February 2015, the European Commission established that Portugal was in excessive macroeconomic imbalance and needed "a decisive policy action and specific monitoring", with special focus in "high levels of external, public and private debt" and in a "highly negative net international investment position" (European Comission, 2015 d, p. 35).

The economic and financial conditions have improved since the assumptions of the first post-programme surveillance mission, in autumn 2014, but the economic recovery is still troubled by the remaining macroeconomic imbalances.

The results of specific monitoring, under the Macroeconomic Imbalance Procedure (MIP), suggest that Portugal has made some progress in addressing the relevant imbalances but the 2015 in-depth review (IDR) conclude that the remain excessive macroeconomic imbalances require decisive policy action and specific monitoring (European Commission, Economic and Financial Affairs, 2015, p. 4).

One of the most undesirable imbalances is the public debt, in excess all over the period of 2009-2015 (Table 1). Portugal owns the highest debt, among all the countries in analysis and the Euro Area, between 2011 and 2015 , and ever above $60 \%$ of the GDP.

The risky context of the financial crisis and the recession, the high public deficits, the reclassification of entities into the general government (GG) perimeter and its interventions in the financial system increase the complexity of the public debt correction strategy.

In this scenario, the GG (S13) intervention strategy in the financial system must follow the information prepared by the supplementary tables for reporting government interventions to support the Portugal financial institutions (Table 5).

Table 5: Portugal - Outstanding amount of Assets, actual Liabilities and Contingent Liabilities of General Government (S13)

\begin{tabular}{|l|r|r|r|r|r|r|r|}
\hline & 2009 & 2010 & 2011 & $\mathbf{2 0 1 2}$ & $\mathbf{2 0 1 3}$ & $\mathbf{2 0 1 4}$ & $\mathbf{2 0 1 5}$ \\
\hline Assets - Liabilities & 395 & -25 & -892 & -2013 & -2598 & -7725 & -10798 \\
\hline BF90 (S13) & -123368 & -127783 & -117400 & -152491 & -168090 & -188240 & -195150 \\
\hline Assets - Liabilities (\% BF90 from S13) & $-0,3$ & 0,0 & 0,8 & 1,3 & 1,5 & 4,1 & 5,5 \\
\hline Contingent liabilities & 8350 & 5275 & 15850 & 16525 & 16275 & 6300 & 6300 \\
\hline Contingent Liabilities (\% of BF90 from S13) & $-6,8$ & $-4,1$ & $-13,5$ & $-10,8$ & $-9,7$ & $-3,3$ & $-3,2$ \\
\hline
\end{tabular}

Sources: own elaboration: based on Supplementary table for reporting government interventions to support financial institutions, Portugal, 15-04-2016 (Eurostat, 2016 d) and on Annual Accounts by Institutional Sector, Portugal, last update 28 April, 2016, in millions of national currency, euro fixed series, current prices (Eurostat, $2016 \mathrm{c}$ ) .

In comments of the supra mentioned supplementary table for Portugal we can read: "The table includes also capital increases in Caixa Geral de Depósitos (CGD) aimed at enhancing its solvency beyond the regulatory level requirements, which should not be associated with the financial turmoil. In fact, CGD solvency ratio was: $11.4 \%, 11.7 \%, 13.9 \%$ and $15.0 \%$ in $2007,2008,2009$ and 2010 , respectively". 
Nonetheless, given that CGD is a public bank those operations are considered as public interventions for the purpose of the supplementary table. The amounts are recorded at nominal value and a counterpart liability is recorded as an imputed financing. The capital increase in CGD in 2007 occurred in 31.12.2007, and, therefore, no financing costs have been imputed. Additionally, no dividends were imputed in this year (Eurostat, 2016).

The general government (GG) interventions, in the financial sector, between 2010 and 2015, pushed down its Net Financial Wealth (BF90); the Assets minus Liabilities (in percentage of BF90 from S13) have an increased influence all over the period 2010-2015 - precisely the same for the highest public debt in Portugal.

The Contingent Liabilities, in percentage of BF90 of S13, are heavy and mostly heavy between 2011 and 2013 , and we must be aware of this risky situation for the public sector debt sustainability.

Spain is in the stage of macroeconomic imbalances which require specific monitoring and decisive policy. The adjustment identified in 2013 as excessive "has clearly advanced and the return to positive growth has reduced risks" (European Commission, Directorate General for Economic and Financial Affaires, 2014, p. 3). But the amount and the inter-related nature of the imbalances, as the internal and external debt levels, made the risk very present. So, the Commission will continue on the trail of a specific monitoring, in the context of the European Semester.

The recapitalization and the restructuring of some banks, in need, have dissipated some systemic risks arising from the financial sector and endorsed a suave ending of the financial assistance programme by 2014. But the adjustment it is not finished and the vulnerabilities don't disappear. The higher social expenditure, with a high and persistent unemployment, and the bank recapitalisation costs pressure the government deficit and the rise in general government gross debt. And due "to exceptional macroeconomic conditions, in July 2013, the council extended the deadline for correcting the excessive deficit by two years to 2016 " (European Commission, Directorate General for Economic and Financial Affaires, 2014, p. 10). In fact, the deficits accumulation - and its high level - makes more difficult to fight the excessive indebtedness (Figure 5).

The imbalances accumulated in the private financial and non financial sectors have multiple interactions with the general government witch debt increases between 2010 and 2014; only in 2009 it is note above 60\% (Table 1).

The rule of the "alignment between revenues and expenditures in the medium term" (European Commission, Directorate General for Economic and Financial Affaires, 2014, p. 12) for the reduction of deficits, the public administration reforms and the structural measures for the stability of public finances could open the way of ending the risky of imbalances.

And the interactions between the general government and the financial sector?

Figure 5: Spain- General Government Deficit (B9), in percentage of GDP

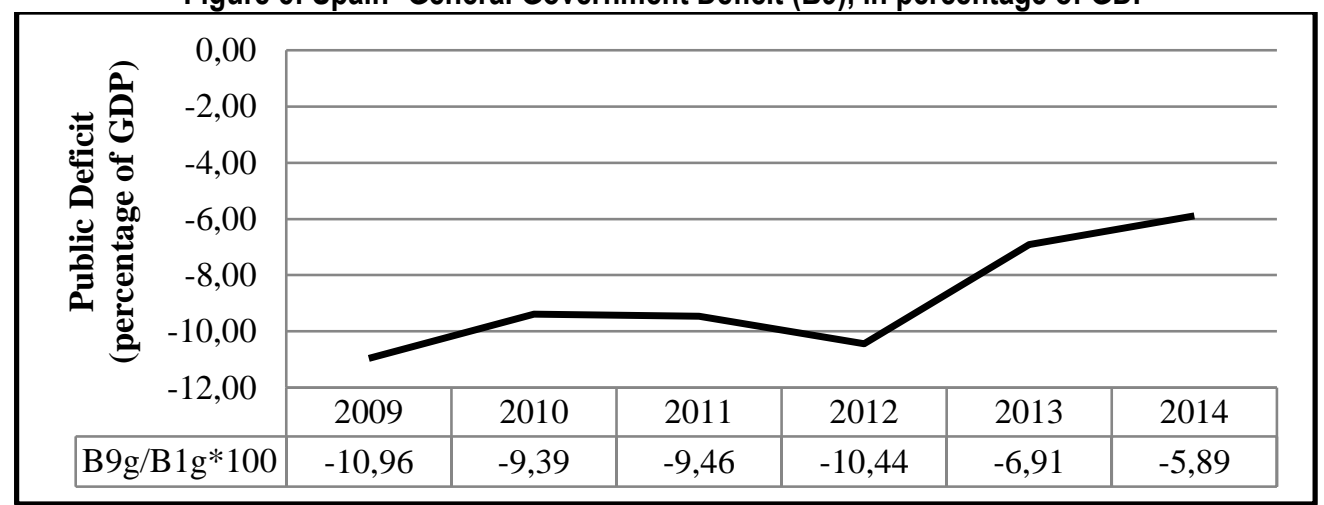

Source: own elaboration: based on Annual Accounts by Institutional Sector, Spain, last update 28 April, 2016, in millions of national currency, euro fixed series, current prices (Eurostat, 2016 c).

All over the period, under obseration (Table 6) the rescue operations have a negative impact on the General Government (S13) Net Financial Wealth (BF90), mainy in 2012; The Assets-Liabilities (in percentage of BF90 from S13) represents $6,5 \%$ - the year of the set up of a financial stability support programme. 
Table 6: Spain - Outstanding amount of Assets, actual Liabilities and Contingent Liabilities of General Government (S13)

\begin{tabular}{|l|r|r|r|r|r|r|r|}
\hline & $\mathbf{2 0 0 9}$ & $\mathbf{2 0 1 0}$ & $\mathbf{2 0 1 1}$ & $\mathbf{2 0 1 2}$ & $\mathbf{2 0 1 3}$ & $\mathbf{2 0 1 4}$ & $\mathbf{2 0 1 5}$ \\
\hline Assets-Liabilities & 684 & 1456 & -2060 & -40349 & -43367 & -44364 & -45217 \\
\hline BF90 (S13) & -364263 & -426188 & -514345 & -616496 & -725698 & -862897 & $\mathrm{na}$ \\
\hline Assets-Liabilities (\% of BF90 from S13) & $-0,2$ & $-0,3$ & 0,4 & 6,5 & 6,0 & 5,1 & $\mathrm{na}$ \\
\hline Contingent Liabilities & 49008 & 59506 & 64659 & 105093 & 95604 & 55090 & 46385 \\
\hline Contingent Liabilities (\% of BF90) & $-13,5$ & $-14,0$ & $-12,6$ & $-17,0$ & $-13,2$ & $-6,4$ & $\mathrm{na}$ \\
\hline
\end{tabular}

Sources: own elaboration: based on Supplementary table for reporting government interventions to support financial institutions, 31 03-2016 (Eurostat, 2016 d) and on Eurostat, Annual Accounts by Institutional Sector, Spain, last update 28 April, 2016, in millions of national currency, euro fixed series, current prices (Eurostat, $2016 \mathrm{c}$ ) .

Also the Contingent Liabities represent a large percentage of S13 Financial Wealth $(17,0 \%$, in 2012$)$ what's open the fear of the banking crisis consequences on the sector of general government indebteness.

In this context, Spain make the decision to enter in a support programme, set up in July 2012, to end the negative feedback loops into the sovereign debt market. "In June 2012, the spanish government requested financial assistance for the recapitalisation of financial institutions" by the European Financial Stability Facility (EFSF) to be later taken over by the European Stability Mechanism (ESM); this request was approved by the Eurogroup in July 2012 (European Commission, Economic and Financial Afairs, 2016, p. 7)

The programme involved a package of financial assistance by EFSM/ESM to be channelled through the Fund for the Orderly Restructuring of the Banking Sector (FROB) to the financial institutions in need of general government support. The "ESM disbursed close to EUR 39,5 billion (of which, about 2,5 billion for capitalising Sareb) in December 2012 and a further EUR 1,8 billion in February 2013 " (European Commission, Economic and Financial Afairs, 2016, p. 7).

The general government gross debt to GDP ratio is rising from $2009(52,7 \%)$ to $2011(69,5 \%)$ compelled by strong deficits and capital injections into the banks. And as the EA sovereign debt crisis intensified (in Spain, the general government gross debt increased between 2009-2014 - Table 2.2.1, p.5 ) "acess to funding was becoming a major challenge" (European Commission, Economic and Financial Afairs, 2016, p. 12).

In January 2014, Spain finished the financial stability support programme but its high general government debt, increasing between 2013 and 2014 and for more than $60 \%$ of the GDP in 2015, makes very real the fear of new financial stress in the spanish financial sector.

Spain is in 2015 classified as in imbalance and subject to in-dept reviews (IDRs) that "reflets the specific risks and challenges countries are facing" (European Commission, Directorate General for Economic and Financial Affairs, 2015, p. 9). For Spain the focus have been found in: external rebalancing, households debt and public debt risk. High levels of private debt coexist with the higt households debt; also the " high corporate indebtedness is a source of risks for the financial sector" (European Commission, Directorate General for Economic and Financial Affairs, 2015, p. 19), which can face high ratios of non performing loans and difficulties in supporting the investment and the economic growth.

\subsection{The Balance Sheet recession}

"The wealth of an economy is measured by its net worth (assets less liabilities) and this shown at the bottom of the balance sheet" (Eurostat \& European Commission, 2013, p. 21). And the balanc sheet completes the sequence of accounts and shows the effects of the registration on them over the stock of wealth of an economy. For the total national economy the balancing item of a financial balance sheet (BF90) may be referred as national financial wealth (Eurostat \& European Commission, 2013). In the BPM6 the corresponding balance sheet "drawn from the view point of residentes vis-à-vis non residents is called the international investment position (IIP)" (Eurostat \& European Commission, 2013, p. 169).

And where is the Balance sheet recession? The recession is very present when is used the ratio BF90 (net financial wealth) in percentage of GDP ; in fact GDP is the most important link with the economic system and with the country net financial wealth sometimes called net worth; this one, being positive or negative, makes 
From the financial crisis to the Balanced Sheet recession: an empirical analysis based on the National Accounts.

all the diference in terms of the deb sustainability that spread from the sectors towards all the country and the Rest of the world.

By using, again, the empirical study lets observe and make the necessary assumptions about the Balance Sheets, by institutional sectors, for the five countries.

\subsubsection{Balance Sheet recession in Austria}

As demonstrated, at point 2.2, Austrian banks have, in this period of analysis, needs to transform their business models, and recapitalizations with the general government interventions, to be more resilient in an open and crisis context.

Strong interlinkages occur between general government sector and the financial sector, under the form of "outstanding amount of assets, actual liabilities and contingent liabilities" and directly over the general government balance sheet (Figure 6).

Figure 6 - Austria - Net Financial Wealth (\% of GDP) From Institutional Sectors

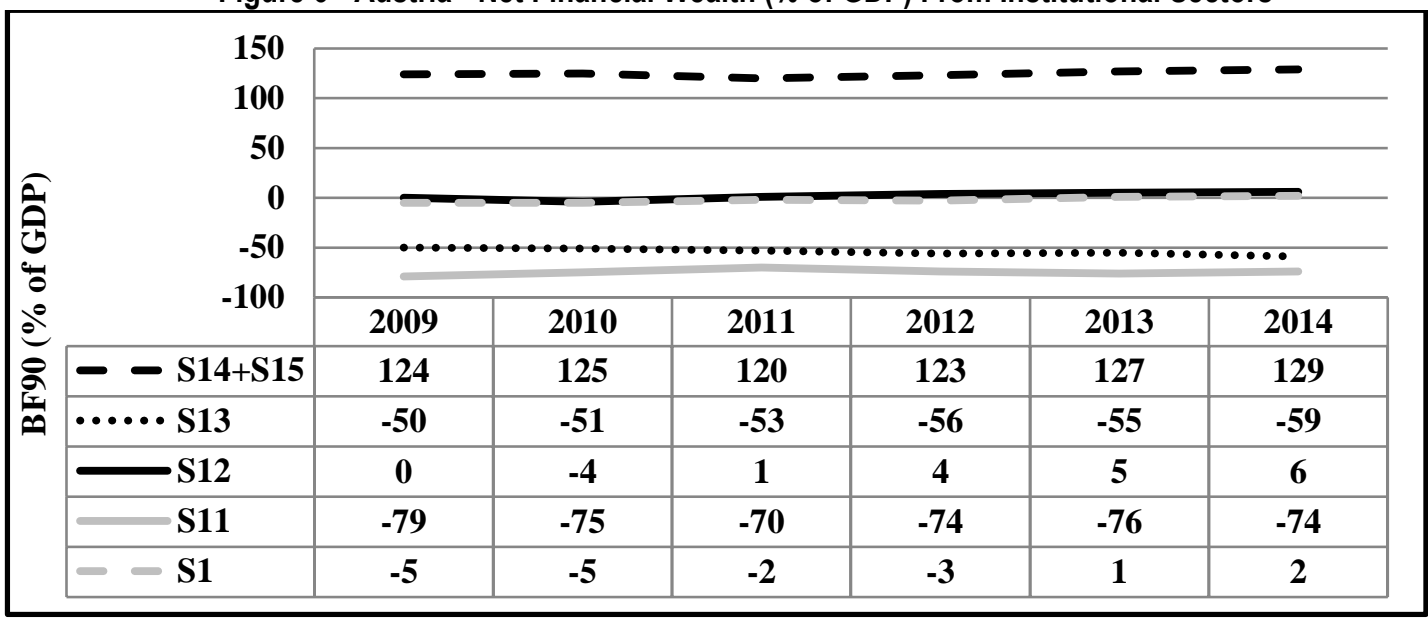

Source: own elaboration: based on Annual Accounts by Institutional Sector, Austria, last update 28 April, 2016, in millions of national currency, euro fixed series, current prices (Eurostat, $2016 \mathrm{c}$ ) .

The referred inter relations have strong negative consequences over the net financial wealth (in percentage of GDP) of the sector of general government (S13) and over the sector (S12) net financial wealth, in recuperation, mainly after 2011, in result of some interventions measures.

And above all, the sector of non-financial corporations (S11), between 2009 and 2014, is in a net financial wealth bad position mainly related to the small and medium enterprises (SME) credit needs and in result of its banking sector's dependence, also in stress and struggling for capital.

The high Households ( $\mathrm{S} 14+\mathrm{S} 15$ ) net financial wealth (in percentage of GDP) is projected to increase after the tax-relief to this institutional sector, driven by the tax reform in 2016. It is a fiscal policy measure to support the domestic demand and to foster the economic recovery.

The behavior of the all the sectors ( $\mathrm{S} 11$ to $\mathrm{S} 14+\mathrm{S} 15$ ) compromise the country net financial wealth of the country (S1) and so the international investment position (IIP) of Austria. 


\subsubsection{Balance Sheet recession in Belgium}

As we can see (Figure 7) the situation of the Households net financial wealth (in \% of GDP) is very good all over 2009-2014.

The supra referred situation is in relation with the Households saving rate - defined as the gross saving (B8g), in percentage of the disposable income (B6g), this one with the correction of the Adjustment for the change in pensions entitlements (D8) - is in a dynamic performance (Table 7) to construct a healthy financial situation for the Belgium Households (we work with households and nonprofit institutions in the service of households, because of the information source).

Figure 7 - Belgium - Net Financial Wealth (\% of GDP) From Institutional Sectors

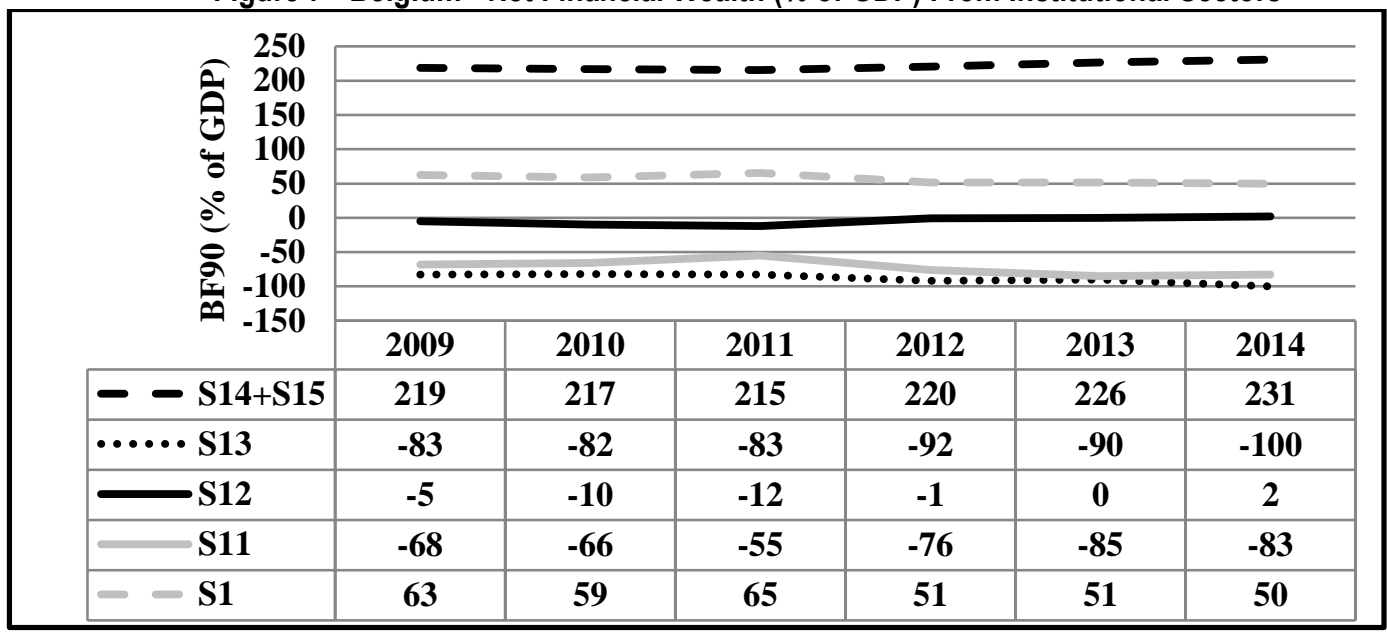

Source: own elaboration: based on Annual Accounts by Institutional Sector, Belgium, last update 28 April, 2016, in millions of national currency, euro fixed series, current prices (Eurostat, $2016 \mathrm{c}$ ) .

Table 7: Belgium Households (S14+S15) Saving Rate

\begin{tabular}{|l|c|c|c|c|c|c|}
\hline & $\mathbf{2 0 0 9}$ & $\mathbf{2 0 1 0}$ & $\mathbf{2 0 1 1}$ & $\mathbf{2 0 1 2}$ & $\mathbf{2 0 1 3}$ & $\mathbf{2 0 1 4}$ \\
\hline (B8g)/ (B6g+D8)*100 & 18 & 15 & 14 & 13 & 12 & 13 \\
\hline
\end{tabular}

a) B8g-Gross Save

b) B6g+D8 - Disposable Income with adjustment

Source: own elaboration: based on Annual Accounts by Institutional Sector, Belgium, last update 28 April, 2016, in millions of national currency, euro fixed series, current prices (Eurostat, $2016 \mathrm{c}$ ).

The danger exists in relation to the behavior of the house market and on the conditions for lending that increase the households debt. The financial sector, generally considered a healthy sector, mainly in $2013 \mathrm{e}$ 2014, demands, by its vital functions in the Belgium economy, a proactive supervision since the existence of a strong growth in mortgage lending in the country. In fact, the household debt continued to increase in Belgium supported by positive credit flows. So, in case of the debt to income ratio, "there are more households with a higher risk in Belgium than in the euro area"; and the "debt to asset ratio is lower in Belgium" in face of the high value of Belgian households' assets. (European Commission, 2015 c, p. 37).

The non-financial corporation sector (S11) and the general government sector (S13) they both have, all over the period, a negative financial wealth. We must remember that the non-financial corporation sector is a combined sector with private and public corporations; the last with complex financial relations with the general government. 
From the financial crisis to the Balanced Sheet recession: an empirical analysis based on the National Accounts.

The decline of employment is a shadow over the Households sector and over the Welfare State and certainly a risk for the loans coming from the financial sector to be transformed in non-performance and to increase the recession.

Finally, the country (S1) has a good financial position what's made possible, for Belgium, the existence of a positive international investment position.

\subsubsection{Balance Sheet recession in Netherlands}

Several risks associated to the high levels of private and public corporations debts - especially in relation with the non-financial corporation (S11) made its net financial wealth in a very negative performance (Figure 8) - worse than the net financial wealth of general government sector (S13) - this one also fueled by its indebtedness.

Figure 8 - Netherlands - Net Financial Wealth (\% of GDP) From Institutional Sectors

\begin{tabular}{|c|c|c|c|c|c|c|c|}
\hline \multirow{7}{*}{ 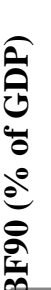 } & \multirow{7}{*}{$\begin{array}{r}\mathbf{2 5 0} \\
\mathbf{2 0 0} \\
\mathbf{1 5 0} \\
\mathbf{1 0 0} \\
\mathbf{5 0} \\
\mathbf{0 0} \\
\mathbf{- 5 0} \\
\mathbf{- 1 0 0} \\
\mathbf{- 1 5 0}\end{array}$} & & & & & & \\
\hline & & \multirow{2}{*}{\multicolumn{6}{|c|}{ 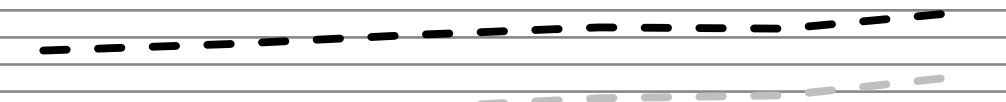 }} \\
\hline & & & & & & & \\
\hline & & & & $-=$ & & & \\
\hline & & \multirow{2}{*}{\multicolumn{6}{|c|}{ 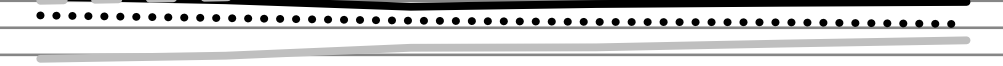 }} \\
\hline & & & & & & & \\
\hline & & 2009 & 2010 & 2011 & 2012 & 2013 & 2014 \\
\hline \multicolumn{2}{|c|}{$-\mathrm{S14+S15}$} & 126 & 138 & 155 & 169 & 166 & 198 \\
\hline \multicolumn{2}{|c|}{$\cdots \cdots \cdot S 13$} & -27 & -32 & -37 & -39 & -40 & -43 \\
\hline \multicolumn{2}{|c|}{$\longrightarrow \mathrm{S} 12$} & 8 & 1 & -11 & -6 & -4 & -2 \\
\hline \multicolumn{2}{|c|}{ S11 } & -107 & -101 & -87 & -86 & -79 & -73 \\
\hline \multicolumn{2}{|c|}{$--\mathbf{S 1}$} & $\mathbf{0}$ & 6 & 20 & 38 & 43 & 80 \\
\hline
\end{tabular}

Source: own elaboration: based on Annual Accounts by Institutional Sector, Netherlands, last update 28 April, 2016, in millions of national currency, euro fixed series, current prices (Eurostat, $2016 \mathrm{c}$ ) .

The sector of financial corporations (S12), supported by the general government, is an important driver of the general government debt and of its negative net financial position (BF90). We can think about the "deadly embrace" between the sovereign and the financial sector.

The households (S14+S15) net financial wealth, in percentage of GDP, is the bigger one, all over the period, and a fundamental explanation for a positive net financial wealth of the country (S1) what's qualify Netherlands to have a favourable investment international investment position (IIP).

\subsubsection{Balance Sheet recession in Portugal}

Portugal, with an excessive corporate debt, from the private and the public enterprises that composes S11, activates the negative non-financial corporations sector (S12) financial wealth, for all over the period (Figure 9); this situation is complemented by an excessive general government (S13) indebtedness, and therefore, to a negative financial wealth of this sector.

The negative net financial wealth of the country (S1) clarifies its very bad shape in relation to the rest of the world sector (S2) and therefore the critical international investment position (IIP). This dynamics is in the center of the country difficulties to stop the recession - so present in the Balance Sheets of its sub sectors. 
Figure 9 - Portugal- Net Financial Wealth (\% of GDP) From Institutional Sectors

\begin{tabular}{|c|c|c|c|c|c|c|c|c|}
\hline \multirow{8}{*}{ 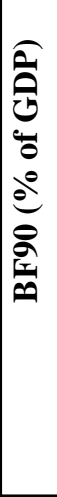 } & \multirow{3}{*}{$\begin{array}{r}150 \\
100 \\
50 \\
-50 \\
-100 \\
-150 \\
-200\end{array}$} & \multicolumn{7}{|c|}{--} \\
\hline & & \multicolumn{7}{|c|}{ 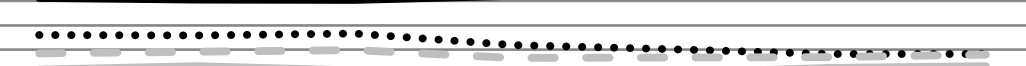 } \\
\hline & & \multirow{2}{*}{$\begin{array}{c}2009 \\
97\end{array}$} & \multirow{2}{*}{\begin{tabular}{|c|}
2010 \\
98
\end{tabular}} & \multirow{2}{*}{\begin{tabular}{|c|}
2011 \\
107
\end{tabular}} & \multirow{2}{*}{$\begin{array}{c}2012 \\
113\end{array}$} & \multirow{2}{*}{$\begin{array}{c}2013 \\
118\end{array}$} & \multirow{2}{*}{$\begin{array}{c}2014 \\
120\end{array}$} & \multirow{2}{*}{$\begin{array}{c}2015 \\
120\end{array}$} \\
\hline & $-\quad-\mathrm{S} 14+\mathrm{S} 15$ & & & & & & & \\
\hline & •...S S13 & -70 & -71 & -67 & -91 & -99 & -109 & -109 \\
\hline & $\longrightarrow \mathrm{S} 12$ & 6 & 3 & 2 & 10 & 13 & 12 & 13 \\
\hline & S11 & -141 & -134 & -143 & -149 & -148 & -138 & -134 \\
\hline & $-\mathbf{S 1}$ & -108 & -104 & -101 & -117 & -116 & -115 & -110 \\
\hline
\end{tabular}

Source: own elaboration: based on Annual Accounts by Institutional Sector, Portugal, last update 28 April, 2016, in millions of national currency, euro fixed series, current prices (Eurostat, $2016 \mathrm{c}$ ).

In fact, Portugal is facing in this period of analysis important risks linked to high levels of indebtedness, internal and external, across all the sectors of the country what's make the Balance Sheet net financial wealth scenario so dark (European Comission, 2015 e) .

\subsubsection{Balance Sheet recession in Spain}

Spain, as we have red before, is experiencing macroeconomic imbalances which require decisive policy action and specific monitoring. The country ends the financial assistance programme for the recapitalization of its financial institutions (S12) in 2014 and is subject to programme surveillance and to the European Semester rules, in 2015.

High levels of private and public sector indebtedness and the negative net financial wealth (BF90) of the Spanish country representing more than 90\% of the GDP, for almost all the period 2009-2014 (Figure 10), deserve a prudently attention mainly in a context of recession and of high unemployment.

The sector of households (S14+S15), mainly between 2009 and 2012, has a net financial wealth very low, when compared with other countries of this study, and this is explained by the bad situation of the sector of non-financial corporations (S11) and therefore by the unemployment.

In Spain, the sector of non-financial corporations (S11) seems to be in a "deadly embrace" with the general government (S13) and the country (S1).

The recession in Spain creates an environment of a very negative net financial wealth for all the country (S1) and thus a bad international investment position (IIP).

This sector behavior, clear in its Balance Sheets, creates a dynamics that is in the center of the Spain difficulties to stop the financial distress and the recession. 
From the financial crisis to the Balanced Sheet recession: an empirical analysis based on the National Accounts.

Figure 10 - Spain - Net Financial Wealth (\% of GDP) From Institutional Sectors

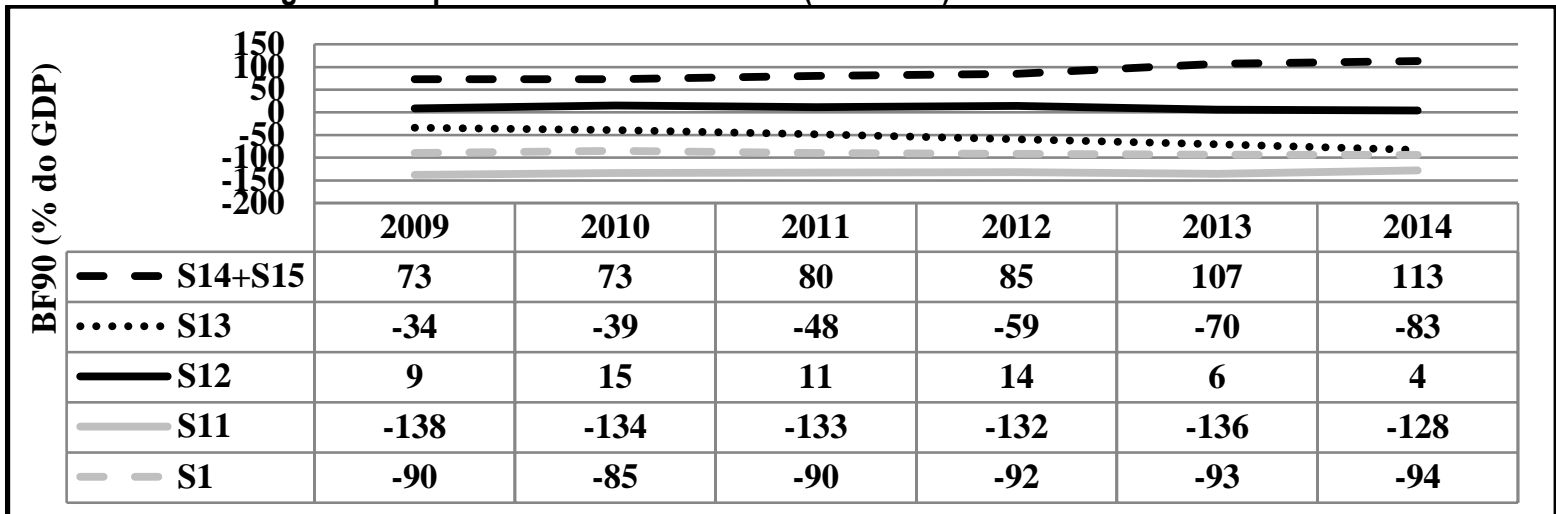

Source: own elaboration: based on Annual Accounts by Institutional Sector, Spain, last update 28 April, 2016, in millions of national currency, euro fixed series, current prices (Eurostat, 2016 c).

\section{Final remarks}

The systemic financial crisis is revealed by the national accounts framework with the employment of ratios used to the national and supranational governance and for the surveillance of the excessive deficit procedure and of the excessive imbalance procedure; the governance strategy purpose is the categorization of the Euro Area Member States and must be followed by a very prudent policy action conductive to a very attractive stage of no imbalances; this stage may happen, for some member states in financial stress, only with the support of the European Central bank (ECB) as a lender of last resort.

The crisis demands a careful and persistent surveillance, at national and supranational level, to reflect the specific risks and challenges countries are facing. A crisis management strategy may safeguard some risky interlinkages between the following institutional sectors: the general government and the financial sector; the financial sector and the non-financial sector and the households; and finally, the general government and the households in the form of the Welfare State various functions.

The supra referred interlinkages, between the sovereign and the banks, are present in all the five countries of this study, but under different strategies, dynamics and models. In this scenario it is important to confirm the crucial role of an adequate management of the general government risk to support the financial sector in crisis.

The macroeconomic Imbalance Procedure (MIP) is a good governance answer for the financial and the balance sheet crisis impacts; the use of suitable indicators, in a supervision governance strategy, is the backbone for the financial stability, the growth and the employment in the European countries and institutions, in general.

The systemic nature of the crisis explained the interlinkages between all the sectors of a country and of the Rest of the World. This opens a governance problem at all its levels - national and European - and domains - economic, social and financial.

This empirical study joints together the countries imbalances nature, as present in the ratios of the institutional sectors accounts or inside their balance sheets.

I conclude that it is no surprising that the interlinkages exist between the sectors and the countries but the so called "deadly embrace", between the general government and the financial sector is also between all the sectors of an economic and financial system and so, the

Governance' strategies must follow the idea that all the institutional sectors are too important to fall.

Europe needs a governance strategy to stop the risky systemic financial links, inside the countries and its supranational relations, improving the regulators actions to stop the financial balance sheet recession, yet so present in the financial Assets and Liabilities composition of several member states' sectors. 


\section{Funding}

This work was financially supported by the research unit on Governance, Competitiveness and Public Policy (project POCI-01-0145-FEDER-006939), funded by FEDER funds through COMPETE2020 - Programa Operacional Competitividade e Internacionalização (POCI) - and by national funds through FCT - Fundação para a Ciência e a Tecnologia.

This paper was presented in the EuroConference, 2016, at Porto, School of Economics, june 2016.

\section{References}

Council of the European Union. (2014 a). Abrogating Decision 2010/282 EU on the existence of an excessive deficit in Austria. at: http://ec.europa.eu/economy_finance/economic_governance/sgp, acess at september 2014: Council of the EU.

Council of the European Union. (2014 b). Abrogation Decision 2010/287/EU on the existence of an excessive deficit in the Netherlands. Luxembourg: EU.

De Nederlandsche Bank . (2014 a). Press release: Reaction of DNB to Evaluation Comittee's report on nationalisation of SNS Reaal. at: www.dnb.nl.

De Nederlandsche Bank. (2008). Government reinforces SNS Reaal's capital position by EUR 750 million - press release. at:www. dnb.nl.

De Nederlandsche Bank. (2014 b). Supervisory Strategy 2014-2018. at: www.dnb.nl: DNB.

European Comission. (2015 d). Report from the Commission to the European Parliament, the Council, The European Central Bank and the Economic and Social Committee, Alert Mechanism Report, 2016. Brussels: EC.

European Comission. (2015 e, June). Macroeconomic imbalances, Country Report, Portugal. European Commission, occasional papers 222.

European Commission. (2015 a, acess at http://ec.europa.eu/economy_finance/publications). European Economic Forecast, Spring 2015. European Economy $n^{\circ}$ 2/2015.

European Commission. (2015 a, May, acess at http://ec.europa.eu/economy_finance/publications). European Economic Forecast, Spring 2015. European Economy 2/2015.

European Commission. (2015 b). Assessemnet of the 2015 Stability Programme for Austria. Brussels, May: EC, Note prepared by ECFIN Staff.

European Commission. (2015 c, June at http://ec.europa.eu/economy_finance/publications). Macroeconomic Imbalances, Country Report, Belgium, 2015. European Economy, occasional papers, 212.

European Commission. (2016 a). Report From the Commission, Belgium, prepared in acordance with Article 126 (3) of the Treaty. Brussels,May: acess at http://ec.europa.eu/economy_finance/publications.

European Commission. (2016 b, May at http:/lec.europa.eu/economy_finance/publications). European Economic Forecast, Spring 2016. European Economy, Institutional Paper 025.

European Commission. (2016). Report from the Commission, Alert Mechanism Report. Brussels: European Commission.

European Commission, Directorate General for Economic and Financial Affaires. (2014, March). Macroeconomic Imbalances, Spain 2014. European Economy, occasional papers 176, p. at: http://ec.europa/economy_finance/publications.

European Commission, Directorate General for Economic and Financial Affairs. (2015, June). Macroeconomic Imbalances, Main Findings of the In-Depth Reviews, 2015. European Economy, Occasional Papers 228 p. http://ec.europa.eu/economy_finance/publications.

European Commission, Directorate General, Economic and Financial Affairs. (2015 a). Assessemnet of the 2015 Stability Programme for The Netherlands, note prepared by DG ECFIN staff. Brussels: EU.

European Commission, Directorate General, Economic and Financial Affairs. (2015 b). Assessement of the 2015 Stability Programme for Portugal (note prepared by DG ECFIN staff). Brussels: European Union, May. 


\section{From the financial crisis to the Balanced Sheet recession: an empirical analysis based on the National Accounts.}

European Commission, Economic and Financial Afairs. (2016, January). Evaluation of the Financial Sector Assistance Programme, Spain, 2012-2014. European Economy- Institutional Paper 019- ISSN 2443-8014.

European Commission, Economic and Financial Affairs. (2015, July). Post-Programme Surveillance Report, Portugal, Spring 2015. European Economy, Institutional Paper 006 - ISSN 1725-3209, p. at http://ec.europa.eu/economy_finance/publications.

European Union. (2016, acess at April). Macroeconomic Imbalances Procedure: Changes in MIP Categories and Member States Categorisation. Retrieved from http://ec.europa.eu/economy_finance/economic_governance/macroeconomic_imbalance_procedure/index_en.htm.

Eurostat \& European Commission. (2013). European System of Accounts - ESA 2010. Luxembourg: European Union. ISBN 978-9279-31242-7.

Eurostat \& European Commission. (2013). European System of Accounts - ESA 2010. Luxembourg: European Union, ISBN 978-9279-31242-7.

Eurostat \& European Commission. (2013). European System of Accounts, ESA2010. Luxembourg: EU, Publications Office.

Eurostat. (2016, March 31). Supplementary Table for Reporting Governing Interventions to Support Financial Institutions. at: http:/ec.europe.eu/eurostat: European Commission,Eurostat.

Eurostat. (2016 a). Consistency Between National Accounts and Balance of Payments. Statistical working papers. Luxembourg: European Union.

Eurostat. (2016, April 28). Annual Accounts by Institutional Sector, Data in ESA 2010 format,Spain. at: http://ec.europa.eu/eurostat: Eurostat.

Eurostat. (2016 b). Supplementary Table for Reporting Government Interventions to Support Financial Institutions. at: http:/ec.europe.eu/eurostat: European Commission,Eurostat.

Eurostat. (2016 c, April 28). Annual Accounts by Institutional Sector, Data in ESA 2010 format. acess at: http://ec.europa.eu/eurostat: Eurostat.

Eurostat. (2016 d, March and April). Supplementary Table for Reporting Governing Interventions to Support Financial Institutions. at: http:/ec.europe.eu/eurostat: European Commission,Eurostat.

Eurostat. (2016). Supplementary Table for Reporting Government Interventions to Support Financial Institutions, Portugal. EC, Eurostat.

Grauwe, P. d. (2013, April). Design Failures in the Eurozone- can they be fixed? European Economy- Economic Papers 491, pp. 130.

International Monetary Fund. (2009). Balance of Payments and International Investment Position Manual. Sixth Edition. BPM6. Washington, DC, USA: IMF.

Nowotny, E. (2010). Central Banking after the Crisis, opening remarks. Vienna: Oesterreichische Nationalbank.

Nowotny, E. (2010). Central Banking after the Crisis,opening remarks. Vienna: Oesterreichische Nationalbank.

Osterreichische National Bank -ONB. (2015). Facts on Austria and its Banks. Vienna, Austria: Osterreichische National Bank - ONB, acess at www.oenb.at, April 2016.

Osterreichische National Bank -ONB. (2015). Financial Stability Report 30, December. Vienna, Austria, at www.oenb.at, acess at April 2016: ONB.

Praet, P. (2016). The ECB and its role as lender of last resort during the crisis. Capital Markets Regulation Conference on The lender of last resort - an international perspective (p. Introduction). Washington DC, 10 February: at www.ecb.europa.eu.

Sousa, V. G. (2011). Sistema Europeu de Contas: o Modelo Contabilístico e a Linguagem Económica para a Análise e a Governação. Porto: Vida Económica, Editorial, S.A ISBN: 978-972-788-399-8.

Sousa, V. G. (2012). Ciência Económica e Formação de uma Linguagem. Revista Estudos do ISCA. Série IV. n³, at http://revistas.ua.pt/index.php/estudosdoisca/issue/view/62. 


\section{DADOS DA AUTORA}

\section{Virgínia Granate Costa e Sousa}

Doutora em Economia pela UBI

Professora Coordenadora do Instituto Superior de Contabilidade e Administração da Universidade de Aveiro Endereço: Rua Associação Humanitária Bombeiros de Aveiro

CEP: 3810-500 - Aveiro - Portugal

E-mail: virginiagranate@ua.pt

Telefone: (351) 234380110 (ext. 45227)

Telemóvel: 933409822

\section{Contribuição dos Autores:}

\begin{tabular}{lc}
\hline Contribuição & $\begin{array}{c}\text { Virgínia } \\
\text { Granate }\end{array}$ \\
\hline 1. Concepção do assunto e tema da pesquisa & $\sqrt{ }$ \\
2. Definição do problema de pesquisa & $\sqrt{ }$ \\
3. Desenvolvimento das hipóteses e constructos da pesquisa & \\
(trabalhos teórico-empíricos) & \\
4. Desenvolvimento das proposições teóricas (trabalhos teóricos & \\
os ensaios teóricos) & $\sqrt{ }$ \\
5. Desenvolvimento da plataforma teórica & $\sqrt{ }$ \\
6. Delineamento dos procedimentos metodológicos & $\sqrt{ }$ \\
7. Processo de coleta de dados & $\sqrt{ }$ \\
8. Análises estatísticas & $\sqrt{ }$ \\
9. Análises e interpretações dos dados coletados & $\sqrt{ }$ \\
10. Considerações finais ou conclusões da pesquisa & $\sqrt{ }$ \\
11. Revisão crítica do manuscrito & $\sqrt{ }$ \\
12. Redação do manuscrito & \\
\hline
\end{tabular}

